\title{
REMOVAL AND RECOVERY OF PHOSPHATE FROM WATER AND WASTEWATER USING METAL-LOADED AGRICULTURAL WASTE-BASED ADSORBENTS: A REVIEW
}

\author{
Megh Raj Pokhrel $^{1 *}$, Bhoj Raj Poudel ${ }^{1}$, Ram Lochan Aryal ${ }^{1}$, Hari Paudyal ${ }^{1}$, Kedar Nath Ghimire $^{1}$ \\ ${ }^{I}$ Central Department of Chemistry, Tribhuvan University, Kirtipur, Kathmandu, Nepal \\ "Corresponding author: meghrajpokhrel2000@ymail.com
}

(Received: March 14, 2019; Revised: June 3, 2019; Accepted: June 17, 2019)

\begin{abstract}
There is a growing research interest in the development of adsorbents based on agricultural wastes (AWs) for the removal of phosphate from waste water sources, which otherwise can cause eutrophication. Nevertheless, due to the lack of active exposed surface sites, raw AWs-based adsorbents are usually inefficient for the adsorption of phosphate from aquatic environment. Consequently, modification of raw adsorbents has been frequently used to improve their phosphate adsorption capacity. Of the various methods of modification, this review paper focused on most widely used chemical modification method. It presents a critical and comprehensive review of the literature on the effectiveness of metalloaded agricultural wastes (MLAWs)-based adsorbents in removing and recovering of phosphate from waste waters. Mechanisms and factors affecting phosphate adsorption as well as phosphate desorption and regeneration from MLAW adsorbents are critically evaluates. If phosphate from waste waters can be of economical value, regeneration may partly overcome the future shortage of global phosphate rock reserves. It is evident from the literature survey presented herein that MLAWs-based adsorbents exhibited as potential adsorbent for the removal/recovery of phosphate from waste waters. However, there still needs a refined practical utility of these adsorbents on a commercial scale, which may serve as the novel, cost effective and environmentally benign methods of modification.
\end{abstract}

Keywords: Phosphate, Adsorption, AWs, MLAWs, Adsorbents

\section{INTRODUCTION}

Phosphorus (P) is an essential micronutrient which contributes to significant growth of all living organism as well as normal functioning of ecosystem especially in aquatic environment for energy transport (Yadav et al. 2018, Slomp \& Chappellen 2007). As a key constituent of DNA, RNA, ATP, phospholipids, teeth and bones, phosphorus plays important role in animals (Karachalios 2012, Biswas et al. 2008). Phosphorus hasindustrial applications such as fertilizer, detergents, paints, corrosion inhibitors, beverages, pharmaceuticals, etc (Biswas et al. 2007). Although trivalent and pentavalent are the main oxidative states of phosphorus, trivalent phosphorus is chemically unstable and prone to oxidation into the pentavalent state. In aqueous solution, phosphorus exists in oxo-anions such as $\mathrm{PO}_{4}{ }^{3-}, \mathrm{HPO}_{4}{ }^{2-}, \mathrm{H}_{2} \mathrm{PO}_{4}^{-}$and $\mathrm{H}_{3} \mathrm{PO}_{4}$ (Pradhan \& Pokhrel 2013).

A large amount of P-containing wastes produced from agriculture and various industries such as fertilizer and detergent in aquatic environment is a potential global problem (Du et al. 2019, Mor et al. 2017, Huang et al. 2017). However, the primary source of phosphate is phosphate rock, which is a non-renewable resource. Phosphate enters the natural water bodies through rock weathering, agricultural run offs, domestic and industrial sewages (Liu et al. 2019a, Shyla \& Nagendrappa 2011, Xu et al. 2011, Riahi et al. 2009). An excessive emission of phosphate in aquatic ecosystem by human activities is one of the main reasons for eutrophication in lakes, ponds, reservoirs, coastal areas and rivers (Liao et al. 2018). This process is naturally controlled by phosphate and nitrogen bioavailability, which could lead to abnormal growth of aquatic plants and creates algal bloom. This causes a depletion of dissolved oxygen levels, loss of aquatic species (fish death) and increase in parasite load, deteriorating the water quality (Yadav et al. 2018, Jyothi et al. 2012, Liao et al. 2018, Naushad et al. 2018). Leaching of phosphate into groundwater through subsoil also deteriorates the drinking water quality causing potential risks to human health and animals. Due to consumption of high concentration of phosphate, kidney damage and osteoporosis have been reported (Mor et al. 2016).

Phosphorous concentration in water exceeding $0.02 \mathrm{mg} / \mathrm{L}$ can potentially cause eutrophication (Mallampati \& Valiyaveettil 2013). To protect surface water from such undesirable phenomenon many national and international water standard authorities have regulated the effluent discharge standard for total phosphorous ranging from 0.1 to $1.0 \mathrm{mg} / \mathrm{L}$ (Boumra et al. 2018). According to EPA guidelines, the maximum permissible level of phosphorous is $0.1 \mathrm{mg} / \mathrm{L}$ and the stringent discharge limit should be less than $0.05 \mathrm{mg} / \mathrm{L}$ (Huang et al. 2009) Tolerance limit of phosphate for industrial effluent to be discharged into public inland surface water in Nepal is 5 $\mathrm{mg} / \mathrm{L}$ (HMG/MoPE 2012). The WHO recommends 5 $\mathrm{mg} / \mathrm{L}$ maximum concentration for phosphate in drinking water (WHO 1993). Thus it is mandatory for the removal 
of phosphate from effluents to meet stringent environmental regulations (Kalmykova \& Fedje 2013).

Excess of phosphate causes adverse effect in the environment. On the other hand, the excessive use of phosphorous ores leads to the fact that the existing global phosphate rock reserves could be exhausted within the next 50-100 years (Nguyen et al. 2014a, Eljmal et al. 2013, Anirudhan et al. 2012, Aryal \& Liakopoulon Kyriakides 2011, Zhang et al. 2012). Thus it is necessary to develop a phosphate recovery process from effluents as an alternative source of phosphate. Hence both the removals and recovery of phosphate are of equal importance (Anirudhan et al. 2012, Biswas et al. 2008) and there is a need to develop a process for the removal and recovery of phosphate from waste waters (Mor et al. 2016, Zhang et al. 2012).

Nowadays, a series of techniques for removing phosphate from aquatic environment have been developed. These techniques can be classified as chemical methods (precipitation, crystallization, ion exchange and adsorption), biological methods (assimilation, enhanced biological phosphorous removal -EBPR, constructed wetlands, waste water stabilization pond) and physical methods (microfiltration, reverse osmosis, electrodialysis and magnetic separation) (Nguyen et al. 2014a, Bhojappa 2009, Benyoucelf \& Amrani, 2011, De-Bashan \& Bashan 2004, Tian et al. 2017, Geng 2018, Irdemez 2006, Wang et al. 2012). Of these methods, biological methods and chemical precipitation are the most commonly used. However, each method has its own demerits (Biswas et al. 2008, Nguyen et al. 2012). Biological methods, i.e., the conventional activated sludge process, can achieve high percentage removal of phosphate, but they are less effective at trace concentration level, which is due to the fact that the presence of insufficient phosphate lowers metabolism of microorganism. In addition, specific care and strict system are often required during implementation of biological methods. Chemical precipitation undergoes difficulty in sludge disposal, high chemical expense and effluent neutralization. The physical methods (reverse osmosis and electrodialysis) have been proven to be either too expensive or inefficient removal (Huang et al. 2017, Kumar et al. 2010, Mallampati \& valiyaveettil, 2013, Zhang et al. 2011). The most extensively commercialized technique is crystallization using calcium or magnesium, which are known as HAP (hydroxyapetite) and MAP (magnesium ammonium phosphate) methods, respectively (Inou et al. 2018, Tanaka \& Shimamura 2005). In the HAP method, phosphate in aqueous solution is recovered as crystalline of hydroxyapatite (equation 1). The MAP method is used for solution containing both phosphate and ammonia, which are recovered as crystalline struvite (magnesium ammonium phosphate) (equation 2). Although HAP and MAP methods are suitable for waste waters containing high concentration of phosphate. They are not applicable for wastewater containing low or trace concentration of phosphate (Inoue et al. 2018).

$$
\begin{aligned}
& 10 \mathrm{Ca}^{2+}+2 \mathrm{OH}^{-}+6 \mathrm{PO}_{4}{ }^{3-} \rightleftharpoons \mathrm{Ca}_{10}(\mathrm{OH})_{2}\left(\mathrm{PO}_{4}\right)_{6} \\
& \mathrm{Mg}^{2+}+\mathrm{NH}_{4}{ }^{+}+\mathrm{PO}_{4}{ }^{3-}+6 \mathrm{H}_{2} \mathrm{O} \rightleftharpoons \mathrm{MgNH}_{4} \mathrm{PO}_{4} \cdot 6 \mathrm{H}_{2} \mathrm{O}(2)
\end{aligned}
$$

Currently, adsorption is the most promising technique for phosphate removal from waste waters due to its simplicity and flexibility of design, ease of operation and maintenance, economically viable with high efficiency, less production of sludge, potential for regeneration and phosphate recovery. Good removal efficiency can be achieved even for trace levels of phosphate from aqueous solution (Jung et al. 2017, Lin et al. 2016, Auwal et al. 2011, Bouamra et al. 2011, Biswas et al. 2008). Adsorption using activated carbon or anion exchange resins is extensively used for phosphate removal. However, they cannot be used as adsorbent for large scale water treatment in poor or developing countries due to incomplete removal and high cost of production. Moreover, the regeneration of activated carbon is difficult due to the use of expensive chemicals (Hokkanen et al. 2016). In recent years, agricultural wastes (AWs) have attracted the interest of researchers in this field due to their natural abundance, low cost and biocompatibility (Liu et al. 2019b, Hokkanen et al. 2016, Bhatnagar et al. 2015, Regmi et al. 2015, Bhattarai et al. 2014). In addition AWs have diversity of functional groups (e.g. $\mathrm{OH}$, -COOH) (Kour 2016). Therefore, AWs can be modified and can be later employed as an ion exchange resin (Xu et al. 2010, Benyoucef \& Amrani 2011). The production of such natural ion-exchange resin from lowcost and abundant AWs might help to reduce the cost of water treatment (Liu et al. 2012, Ngo et al. 2016). The conversions of AWs into sorbents also reduce the disposal problem of AWs themselves, thereby achieving the goal of "waste control by waste" (Liu et al. 2019). In addition, the successful use of phosphate from waste waters will partly overcome the future scarcity of phosphate resulting from exhaustion of global phosphate rock reserves. The practice of converting phosphate in wastewater into fertilizers can generate revenue (Peng et al. 2012).

Although there have been several reviews on the removal of pollutants from water and wastewaters, to best of our knowledge few reviews on removal of phosphates from water and wastewaters by adsorption process have been published. Early reviews focused on the removal of phosphate by chemical precipitation, biological treatment and constructed wetland (De-Bashan \& Bashan 2004, Morse et al. 1998). Some reviews focused only one specific type of adsorbents such as red mud (Wang et al. 2008), layered double hydroxide (Goh et al. 2008), lowcost adsorbents (Gupta et al. 2009), modified agricultural waste/by-products (Nguyen et al. 2014a), mesoporus materials (Hung et al. 2017), metal (hydr)oxide (Liu et al. 2018) and cerium loaded dried orange juice residue 
(Paudyal \& Inoue 2018). Other review papers covered many adsorbents (Westholm 2006, Loganathan et al. 2014). This paper presents a critical and comprehensive review on the removal and recovery of phosphate from water and wastewater using metal-loaded agricultural wastes (MLAWs)-based adsorbents, especially those that have emerged in recent years. The mechanisms, effect of process parameters, desorption of phosphate and regeneration of adsorbents is discussed.

\section{PHOSPHATE ADSORPTION PERFORMANCE BY AWs}

Although there is an increasing research trend of using AWs as phosphate adsorbent, very few studies have been made for the ability of raw AWs to adsorb phosphate. But raw AWs can show very low adsorption capacity as compared to commercial anion exchangers (Krishnan \& Haridas 2008, Nguyen et al. 2013, Xu et al. 2011, Zhang et al. 2012, Riahi et al., Marshal \& Wartelle, 2004, Yeom $\&$ Jung 2009). The adsorption capacities of phosphate by some raw AWs-based adsorbents and various commercial adsorbents are shown in Table 1 and Table 2 respectively. The low phosphate removal efficiency of raw AWs-based adsorbent compared with commercial adsorbents (as shown in Table 1 and Table 2) can be attributed due to the presence of negatively charged functional groups on the surface of lignocellulosic materials of AWs (e.g. -OH, $\mathrm{COOH})$, while the number of positively charged functional groups is limited. Due to the lack of anion binding sites on the polymeric backbone, raw AWs-based adsorbents are supposed to be less effective in removal of anionic pollutants like phosphate, nitrate, fluoride and arsenic from water (Nguyen et al. 2013, Mallampati \& Valiyaveettil 2013, Thapa \& Pokhrel 2013, Paudyal et al. 2012). In addition, the polymeric organic compounds (cellulose, lignocellulose, and lignin) can leach into aqueous solutions from raw AWs-based adsorbent that also potentially suppressed the adsorption capacity for phosphate anion. Thus, to improve the phosphate adsorption capacity and increase the structural stability of lignocellulosic materials, raw AWs need to be modified (Nguyen et al. 2012, Anirudhan et al. 2006).

\section{MODIFICATION OF AWs}

Different approaches have been applied to modify the raw lignocellulosic biomass for better phosphate adsorption. They can be classified into three major groups: cationization (metal loading, quaternization), anionization (sulfate surface coating) and activation (thermal, chemical, or steam). Among these, cationization is the mostly applied method (Han et al. 2005, Nguyen 2014a).

\section{Metal loading}

Metal loading is one of the best modification methods because of its simplicity and effectiveness. It was assumed that loaded metals can be chemically bonded on the surface of AWs by chemical interaction (Han et al. 2005 Shin et al. 2005). The common high-valent metals used for loading of AWs include $\mathrm{Fe}(\mathrm{II}), \mathrm{Fe}(\mathrm{III}), \mathrm{La}(\mathrm{III})$, $\mathrm{Ce}(\mathrm{III}), \mathrm{Zr}(\mathrm{IV}), \mathrm{Zn}(\mathrm{II})$ etc. Each metal has its own advantages and drawbacks when used as modifying agent of AWs. Though La(III) has high adsorption capacity of phosphate and non-toxic, it has limited reusability due to leaking of loaded metals (Zhang et al. 2011, Shin et al. 2005). La(III) was eluted during desorption test with 0.4 $\mathrm{M} \mathrm{HCl}$, when La-loaded orange waste gel was used as phosphate adsorbent (Biswas et al. 2007). Similarly, though $\mathrm{Fe}(\mathrm{II})$ and $\mathrm{Fe}(\mathrm{III})$ salts are cheap, non-toxic and easily available for loading purpose, but their demerit is less adsorption capacity. Nguyen et al. (2013) reported that $\mathrm{Fe}$ (II) leaked from iron loaded okara during adsorption and desorption test. In contrast, the leaking of $\mathrm{Zr}$ (IV) was found to be negligible in the studies conducted on $\mathrm{Zr}(\mathrm{IV})$-loaded saponified orange waste gel (Biswas et al. 2008), Zr-loaded Apple peel (Mallampati \& Viliyaveettil 2013), Zr(IV)-loaded okara (Nguyen et al. $2014 c$ ). Among various metals, $\mathrm{Zr}(\mathrm{IV})$ is the best due to its high affinity, selectivity towards the phosphate, large surface area and chemical stability.

Table 1. Maximum phosphate adsorption capacity $\left(q_{\max }\right)$ of raw AWs-based adsorbents

\begin{tabular}{lcl}
\hline Raw AWs-based adsorbents & $\mathbf{q}_{\mathbf{m a x}}\left(\mathbf{m g ~} \mathbf{P O}_{\mathbf{4}}{ }^{\mathbf{}-} / \mathbf{g}\right)$ & References \\
\hline Coir pith & 4.35 & Krishnan and Haridas (2008) \\
Giant reed scallop shells & 23.00 & Yeom and Jung (2009) \\
Date palm fibers & 13.33 & Riahi et al. $(2009)$ \\
Giant reed & 0.836 & Xu et al. $(2011)$ \\
Palm surface fibers & 26.05 & Ismail (2012) \\
Granular date stones & 26.66 & Ismail (2012) \\
Sugarcane bagasse & 1.10 & Zhang et al. $(2012)$ \\
Raw okara & 2.45 & Nguyen et al. (2013) \\
\hline
\end{tabular}


Removal and Recovery of Phosphate from Water and Wastewater using ...

Table 2. Maximum phosphate adsorption capacity $\left(q_{\max }\right)$ of various commercial adsorbent

\begin{tabular}{|c|c|c|}
\hline Adsorbents & $\mathbf{q}_{\max }\left(\mathrm{mg} \mathrm{PO}_{4}{ }^{3-} / \mathrm{g}\right)$ & References \\
\hline Amberlite IRA - 400 & 32.24 & Marshall and Wartelle (2004) \\
\hline Whatman QA - 52 & 14.26 & Marshall and Wartelle (2004) \\
\hline Duolite A-7 & 31.74 & Anirudhan et al. (2006) \\
\hline Zr-loaded MUROMAC & 132 & Biswas et al. (2008) \\
\hline Zirconium ferrite & 40 & Biswas et al. (2008) \\
\hline Aluminium oxide & 35 & Peleka and Deliyanni (2009) \\
\hline Hydrotalcite & 60 & Peleka and Deliyanni (2009) \\
\hline Dowex & 40.23 & Anirudhan and Senan (2011) \\
\hline Zr-MCM 41 & 3.36 & Jutidamrongphan et al. (2012) \\
\hline Zirconium ferrite & 27.73 & Jutidamrongphan et al. (2012) \\
\hline
\end{tabular}

Raw AWs was treated directly with metal solutions by some researchers (Han et al. 2005, Krishnan \& Haridas 2008, Huang et al. 2009, Kose \& Kivanc 2011, Mallampati \& Valiyaveettil 2013, Shrestha et al. 2019). Krishnan and Haridas (2008) reported that Fe-loaded coir pith was 5-6 times more effective in adsorbing phosphate than the raw coir pith. Directly metal-loaded biosorbents exhibit satisfactory adsorption capacity to the modified conventional adsorbent but still far lower than the commercial adsorbent (Table 2). The raw AWs can effectively adsorb metal ions from water due to the abundance of negatively charged functional groups (e.g. $\mathrm{OH},-\mathrm{COOH})$ on their surfaces. On the other hand, it needs to do some chemical modification of raw AWs before the reaction with metal salt to obtain a remarkable removal of phosphate. The purpose of chemical modification is to improve the adsorption as well as stability of loaded- metals on the surface of AWs and thereby increase the phosphate uptake ability. This can be done by grafting with more carboxyl groups (carboxylation) or pre-treating with basic solutions (saponification) prior to the metal loading (Eberhardt \& Min 2008, Nguyen 2014a, Ngo et al. 2016).

\section{Grafting carboxyl groups (Carboxylation) onto AWs}

It is well known that the $-\mathrm{COOH}$ group is the most responsible functional group for metal adsorption by AWs. Thus, one of the best methods to improve metal adsorption ability is through grafting of more of carboxyl groups onto AWs. The carboxyl groups grafting reaction can be either by etherification with monochloroacetic acid (carboxymethylation), by esterification using succinic anhydride or by oxidation using sodium chlorite (Nada \& Hassan 2006). It is reported that carboxymethylated baggase exhibited the highest metal binding ability and thermal stability than that of succinylated and oxidised bagasse.
The phosphate adsorption capacity by wood particles modified by carboxymethylation and $\mathrm{Fe}(\mathrm{II})$ was 8.47 times higher than that of wood particles directly treated with Fe(II) ( Eberhardt \& Min 2008). They attributed the higher phosphate adsorption capacity to additional binding sites to complex iron ions, which were formed by the reaction of wood particles with carboxymethyl cellulose. Obviously, addition of more carboxyl group into AWs before their reaction with metal salts significantly increases their metal adsorption capacities. As a result, the adsorption of phosphate ions onto metalloaded bio-sorbent increased.

\section{Saponification (Alkali treatment)}

Saponification is another method to increase the metal adsorption ability of AWs. It was done before metal loading (Biswas et al. 2007, 2008, Han et al. 2005, Mallampati \& valiyaveettil 2013, Nguyen et al. 2014c). Biswas et al. (2008) claimed that treatment of orange waste with $\mathrm{Ca}(\mathrm{OH})_{2}$ and $\mathrm{NaOH}$ improved their cation exchange capacity and hence increasing the binding ability of $\mathrm{Zr}(\mathrm{IV})$. As a result, the adsorption of phosphate ions onto $\mathrm{Zr}(\mathrm{IV})$-loaded saponified orange waste was enhanced. Mallampati and Valiyaveettil (2013) saponified apple peels with $\mathrm{NaOH}$ prior to $\mathrm{Zr}$ (IV) loading. Similarly, Nguyen et al. 2014c also saponified Okara with $\mathrm{NaOH}$ before $\mathrm{Fe}(\mathrm{III})$ and $\mathrm{Zr}$ (IV) loading. They suggested that the base treatment hydrolyzed ester groups in the AWs were responsible for metal binding on AWs.

Table 3 summarizes phosphate adsorption performance of some MLAWs-based adsorbents reported in literature. The adsorption capacity $\left(\mathrm{q}_{\max }\right)$ of MLAWs-based adsorbents for phosphate varied depending on the loaded metal, lignocellulosic biomass materials as well as the operating parameters used. Biswas et al. (2008) conducted the most efficient research by using orange waste gel pretreated with base $\left[\mathrm{Ca}(\mathrm{OH})_{2}+\mathrm{NaOH}\right]$ and loaded with 
$\mathrm{ZrOCl}_{2} \cdot 8 \mathrm{H}_{2} \mathrm{O}$ and the value of phosphate adsorption capacity was $175 \mathrm{mg} / \mathrm{g}$. Sugarcane bagasse fiber was first etherificated using monochloroacetic acid and then loaded with $\mathrm{FeCl}_{2}$ in the research conducted by Carvalho et al. (2011) and the phosphate adsorption capacity of such $\mathrm{Fe}(\mathrm{III})$ loaded sugarcane bagasse was $152 \mathrm{mg} / \mathrm{g}$. In terms of $\mathrm{q}_{\max }$, these two metal-loaded adsorbents are even better than the commercially available ion exchangers listed in Table 2.

\section{PHOSPATE ADSORPTION MECHANISM}

The adsorption capacity and kinetics for phosphate adsorption are controlled by the mechanism of adsorption. Understanding the mechanism can provide useful information on the optimization of adsorption process and subsequent desorption/regeneration process. Various information regarding $\mathrm{pH}$ profile, kinetics, activation energy, desorption etc. and characterization techniques such as FTIR, XRD, SEM, XPS, EDXA etc. have been used to determine the mechanism of adsorption process. The predominant type of mechanism operating in adsorption process depends upon the physical and chemical characteristics of the biosorbent and the environmental/ operational condition (Loganathan et al. 2014). Ligand exchange and surface precipitation are reported mechanism for the adsorption of phosphate onto MLAWs biosorbents. Due to the complex nature of the phosphate adsorption process using MLAWs, it is obvious that several mechanisms may co-exist (Nguyen et al. 2014a).

\section{Ligand exchange (Inner sphere surface complexation)}

Ligand exchange is considered as chemical sorption, which is characterized by fast, strong and less reversible. In this mechanism, the phosphate anions form a covalent chemical bond with a metallic cation on the surface of biosorbents resulting in the release of other anions (e.g. $\mathrm{OH}^{-}$), previously bonded to the metallic cation. Thus, phosphate is said to form an inner sphere complex at the biosorbents surface. The adsorption creates a negative charge on variable charge surfaces, thereby converting the zero point of charge to a lower $\mathrm{pH}$ (Loganathan et al. 2014). A typical method to predict the type of adsorption is based on the activation energy $(\mathrm{E})$ value. While $\mathrm{E}$ value in the range of $8-16 \mathrm{~kJ} / \mathrm{mol}$ represents the chemical sorption, E value lower than $8 \mathrm{~kJ} / \mathrm{mol}$ stand for physical sorption. Similarly, based on the effect of $\mathrm{pH}$, Biswas (2008) interpreted the results of adsorption test in terms of ligand exchange mechanism between phosphate species in the solution and hydroxyl ions/or water molecules coordinate with metal ion-loaded on the SOW gel as shown in Fig. 2. The author suggested that the loaded metal ions $\mathrm{La}(\mathrm{III}), \mathrm{Ce}(\mathrm{III})$ and $\mathrm{Zr}(\mathrm{IV})$ tend to extensively polymerized and hydrolyzed even at very low concentration and converted to $\left[\mathrm{La}\left(\mathrm{H}_{2} \mathrm{O}\right) \mathrm{n}\right]^{3+}$, $\left[\mathrm{Ce}\left(\mathrm{H}_{2} \mathrm{O}\right) \mathrm{n}\right]^{3+}, \quad\left[\mathrm{Zr}_{4}(\mathrm{OH})_{8}\left(\mathrm{H}_{2} \mathrm{O}\right)_{16}\right]^{8+}$ and
$\left[\mathrm{Zr}_{8}(\mathrm{OH})_{20}\left(\mathrm{H}_{2} \mathrm{O}\right)_{24}\right]^{12+}$ species with $\mathrm{OH}^{-}$ions as well as water molecules for ligand exchange with phosphate species (Biswas 2008).

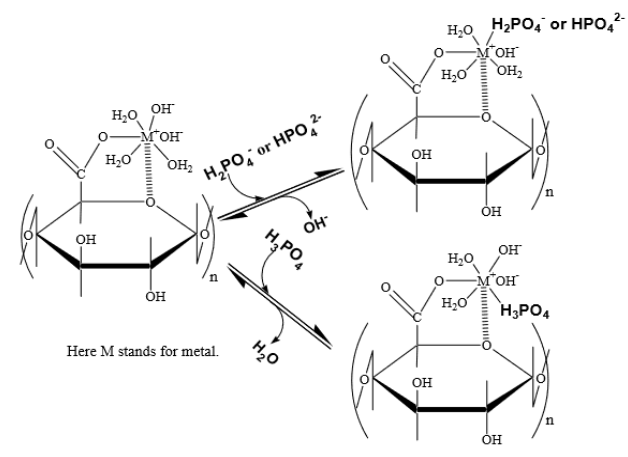

Fig. 2. Inferred mechanism for phosphate adsorption onto metal-loaded SOW gels (Biswas 2008)

\section{Surface precipitation}

A decrease in phosphate content, results not only from adsorption but also from precipitation of phosphate in solution phase. When the solution concentration of components of precipitate exceeds the solubility product of the precipitate, the precipitation of phosphate with metallic ions may take place on the surface of biosorbent (Ngo et al. 2016). According to the thermodynamic solubility product principle, surface precipitation of metal phosphate can occur even at solution concentration of metals and phosphate lower than those expected to from metal precipitates in solution phase (Loganathan et al. 2014). Surface precipitation mechanism is considered as a fast and hardly reversible adsorption (Nguyen et.al. 2014a). Based on the XRD data and FTIR results, Shin et al. (2005) verified the contribution of surface precipitation to the phosphate binding onto La(III) loaded juniper bark fiber. Using kinetic studies, Namasivayam et al. (2005) concluded that the removal of phosphate by oyster shell powder (OSP) was through precipitation as calcium phosphate and then converted into hydroxyapatite on the surface of OSP.

\section{Ion exchange (Outer sphere surface complexation)}

Ion exchange is considered as electrostatic attraction. It is associated with rapid, weak and reversible sorption, which occurs through outer sphere complex. It is a stoichiometric process where any labile ion on the surface of ion exchange is replaced by chemically equivalent number of another counter ion to maintain the electrical neutrality. The force of attraction between the ion and sorbent is electrostatic and hence the adsorption process is reversible (Loganathan et al. 2014).

\section{Intra-particle diffusion}

This process is also known as physical sorption, which takes place inside pores and cavities of AWs. It is 
characterized by irreversible and very slow sorption, which may last for days to months. Intra-particle diffusion rate is directly related to the square root of the time of sorption. If intra-particle diffusion mechanism follows, a plot between phosphate adsorption capacity and the square root of contact time should be straight line passing through the origin (Loganathan et al. 2014).

\section{Table 3. Modifying reagents, $q_{\max }$ and optimum $\mathrm{pH}$ of MLAWs-based adsorbents}

\begin{tabular}{|c|c|c|c|c|}
\hline Adsorbents & Modifying reagents & $\mathbf{q}_{\max }\left(\mathbf{m g} / \mathrm{PO}_{4}{ }^{3-} \mathrm{g}\right)$ & pH & References \\
\hline $\begin{array}{l}\text { Zn-treated Coir } \\
\text { pith carbon }\end{array}$ & $\mathrm{ZnCl}_{2}$ & 5.10 & $3-10$ & Namasivayam \& Sangeetha (2004) \\
\hline $\begin{array}{l}\text { La-loaded Juniper } \\
\text { bark fiber }\end{array}$ & $\begin{array}{l}0.01 \mathrm{M} \mathrm{La}\left(\mathrm{NO}_{3}\right)_{3} \cdot 6 \mathrm{H}_{2} \mathrm{O} \\
0.1 \mathrm{M} \mathrm{La}\left(\mathrm{NO}_{3}\right)_{3} \cdot 6 \mathrm{H}_{2} \mathrm{O}\end{array}$ & $\begin{array}{l}20.05 \\
33.35\end{array}$ & 6 & Shin et al. (2005) \\
\hline $\begin{array}{l}\mathrm{La} / \mathrm{Ce}(\mathrm{III}) \text {-loaded } \\
\text { orange waste gel }\end{array}$ & $\begin{array}{l}\mathrm{Ca}(\mathrm{OH})_{2}+0.01 \mathrm{M} \\
\mathrm{La}(\mathrm{III}) / \mathrm{Ce}(\mathrm{III})\end{array}$ & 42.72 & $7-10$ & Biswas et al. (2007) \\
\hline $\begin{array}{l}\mathrm{Fe}(\mathrm{III}) \text {-loaded } \\
\text { orange waste gel }\end{array}$ & $\mathrm{Ca}(\mathrm{OH})_{2}+0.01 \mathrm{M} \mathrm{Fe}(\mathrm{III})$ & 42.72 & 3 & Biswas et al. (2007) \\
\hline $\begin{array}{l}\mathrm{Fe}(\mathrm{II}) \text {-loaded } \\
\text { wood particles }\end{array}$ & $\begin{array}{l}\mathrm{Fe}(\mathrm{II}) \text { Salt } \\
4 \% \mathrm{CMC}+12 \% \mathrm{FeCl}_{2}\end{array}$ & $\begin{array}{c}2.05 \\
17.38\end{array}$ & 4.8 & Eberhardt \& Min (2008) \\
\hline $\begin{array}{l}\mathrm{Zr}(\mathrm{IV}) \text {-loaded } \\
\text { orange waste gel }\end{array}$ & $\begin{array}{l}\mathrm{Ca}(\mathrm{OH})_{2}+\mathrm{NaOH}+0.1 \mathrm{M} \\
\mathrm{ZrOCl}_{2} \cdot 8 \mathrm{H}_{2} \mathrm{O}\end{array}$ & 175 & $3-9$ & Biswas et al. (2008) \\
\hline $\begin{array}{l}\mathrm{Fe}(\mathrm{III}) \text {-treated } \\
\text { coir pith }\end{array}$ & $\mathrm{Fe}\left(\mathrm{NO}_{3}\right)_{3} \cdot 9 \mathrm{H}_{2} \mathrm{O}$ & 22.05 & 3 & Krishnan \& Hardias (2008) \\
\hline $\begin{array}{l}\mathrm{Al} / \mathrm{Fe}(\mathrm{III}) \text {-loaded } \\
\text { skin split waste }\end{array}$ & $\begin{array}{l}\mathrm{Al}(\mathrm{III}) \text { salt } \\
\mathrm{Fe}(\mathrm{III}) \text { salt }\end{array}$ & $\begin{array}{l}21.65 \\
72.00\end{array}$ & 7 & Huang et al. (2009) \\
\hline $\begin{array}{l}\mathrm{Fe}(\mathrm{II}) \text {-loaded } \\
\text { sugarcane bagasse }\end{array}$ & $\begin{array}{l}\text { monochlaroacetic acid } \\
\text { (carboxymethylation) }+\mathrm{FeCl}_{2}\end{array}$ & 152 & - & Carvalho et al. (2011) \\
\hline $\begin{array}{l}\text { Zr-loaded apple } \\
\text { Peels }\end{array}$ & $\begin{array}{l}\mathrm{NaOH}+0.1 \mathrm{M} \\
\mathrm{ZrO}_{2} \mathrm{Cl} .8 \mathrm{H}_{2} \mathrm{O}\end{array}$ & 20.35 & 2 & Mallampati \& viliyaveettil (2013) \\
\hline $\begin{array}{l}\text { Fe(III)-loaded } \\
\text { okara (ILO) }\end{array}$ & $\mathrm{NaOH}+0.25 \mathrm{M} \mathrm{FeCl}_{3}$ & 16.66 & 3 & Nguyen et al. (2013) \\
\hline $\begin{array}{l}\mathrm{Zr}(\mathrm{III}) \text {-loaded } \\
\text { okara (ZLO) }\end{array}$ & $\begin{array}{l}\mathrm{NaOH}+0.25 \mathrm{M} \\
\mathrm{ZrO}_{2} \mathrm{Cl} .8 \mathrm{H}_{2} \mathrm{O}\end{array}$ & 44.13 & $2-6$ & Nguyen et al. (2014b) \\
\hline $\begin{array}{l}\text { Fe/Zr-loaded } \\
\text { okara (IZLO) }\end{array}$ & $\begin{array}{l}\mathrm{NaOH}+0.25 \mathrm{FeCl}_{3}+0.25 \\
\mathrm{M} \mathrm{ZrO}_{2} \mathrm{Cl} .8 \mathrm{H}_{2} \mathrm{O}\end{array}$ & 40.96 & $\begin{array}{l}\text { Neutral } \\
\mathrm{pH}\end{array}$ & Nguyen et al. (2014c) \\
\hline $\begin{array}{l}\text { La(III)-loaded } \\
\text { pine needles }\end{array}$ & $\begin{array}{l}\mathrm{NaOH}+\text { isopropanol + } \\
0.1 \mathrm{M} \mathrm{La}\left(\mathrm{NO}_{3}\right)_{2} \cdot 6 \mathrm{H}_{2} \mathrm{O}\end{array}$ & 14.7 & 3 & Wang et al. (2015) \\
\hline $\begin{array}{l}\mathrm{Ca}(\mathrm{OH})_{2} \text { treated } \\
\text { Phragmites sp. }\end{array}$ & $\mathrm{Ca}(\mathrm{OH})_{2}$ & 37.55 & 7 & Markou et al. (2016) \\
\hline $\begin{array}{l}\text { Fe(III)-loaded } \\
\text { litchi seed waste }\end{array}$ & $\mathrm{FeCl}_{3} \cdot 6 \mathrm{H}_{2} \mathrm{O}$ & $\begin{array}{c}96.5 \text { (Fe-raw) } 100 \\
\text { (Fe-charred) }\end{array}$ & 3 & Shrestha et al. (2018) \\
\hline
\end{tabular}

\section{PHOSPHATE ADSORPTION FACTORS}

\section{Effect of pH}

The $\mathrm{pH}$ of the aqueous solution is an important variable which influences the adsorption of both anions and cations at the solid liquid interface. The $\mathrm{pH}$ value of the solution influences the dissociation, phosphate species abundance, the chemical state of binding sites and affinity of phosphate species towards binding sites. The $\mathrm{pH}$ profiles are useful for determining adsorption mechanism, 
optimizing process and selecting appropriate eluting reagents. Thus, efforts have been directed towards identifying optimum $\mathrm{pH}$ values in various $\mathrm{AWs}-\mathrm{PO}_{4}{ }^{3-}$ adsorption system (Ngo et al. 2016). In aqueous environment, phosphate can exist in different ionic species such as monovalent $\mathrm{H}_{2} \mathrm{PO}_{4}{ }^{-1}$, divalent $\mathrm{HPO}_{4}{ }^{2-}$ and trivalent $\mathrm{PO}_{4}{ }^{3-}$ ions, depending on the $\mathrm{pH}$ of the solution $\left(\mathrm{pK}_{1}=2.15, \mathrm{pK}_{2}=7.20, \mathrm{pK}_{3}=12.33\right)($ Biswas 2008). Consequently, the dominant species of phosphate species can vary, depending on the $\mathrm{pH}$ value of the aquatic medium. At the $\mathrm{pH}$ range between 4 to $9, \mathrm{H}_{2} \mathrm{PO}_{4}^{-}$and $\mathrm{HPO}_{4}{ }^{2-}$ species were dominant (Biswas 2008). Due to their strong affinity towards binding site, the adsorption of phosphate onto MLAWs was enhanced. But, at $\mathrm{PH}<4$, the dominant species $\mathrm{H}_{2} \mathrm{PO}_{4}^{-}$becomes protonated to $\mathrm{H}_{3} \mathrm{PO}_{4}$, which are considered to substitute neutral water molecule from the hydrated metal ions loaded on to AWs. These neutral species have low affinity towards binding site, which led to poor removal of phosphate from the solution at low $\mathrm{pH}$. In the same way, at the $\mathrm{pH}>9$, $\mathrm{HPO}_{4}{ }^{2-}$ and $\mathrm{PO}_{4}{ }^{3-}$ species were predominant. The weak affinity of these species for binding site associated with strong competition between $\mathrm{OH}^{-}$ions and $\mathrm{PO}_{4}{ }^{3-}$ ions for adsorption site hindered the process. Hence, AWs based adsorbents effectively adsorb phosphate anions in a specific $\mathrm{pH}$ range, while extremely acidic or alkaline medium is found to suppress the process. The reported optimum values in various MLAWs-based adsorbent phosphate adsorption systems are listed in Table 3.

Biswas et al. (2008) found that $\mathrm{pH}$ range of 3-9 (optimum $\mathrm{pH} 3$ ) favored the highest adsorption of phosphate onto $\mathrm{Zr}(\mathrm{IV})$-loaded saponified orange waste (SOW) gel. Similarly, 3-10 for $\mathrm{ZnCl}_{2}$ treated coir pith carbon (Namasivyam \& sangeetha 2004). They found that an increase in $\mathrm{pH}$ value led to decrease in phosphate uptake. The authors justified this phenomenon by stronger repulsion force in alkaline medium. Mallampati and Valiyaveettil (2013), Krishnan and Haridas (2008) and Shrestha et al. (2019) reported low optimum $\mathrm{pH}$ value of 3 and such low optimum $\mathrm{pH}$ was justified by the dominance of $\mathrm{HPO}_{4}{ }^{2-}$ species and their affinity towards binding sites in acidic medium.

\section{Effect of temperature}

Normally, the adsorptive removal of phosphate by AWsbased adsorbent is temperature sensitive. Kumar et al. (2010), Yeom and Jung (2009), Benyoncef and Amrani (2011) and Peng et al. (2012) reported that adsorption capacity of phosphate increased with increasing temperature of solution. This phenomenon is due to expansion of pore size and activation of adsorbent surface at higher temperature (Benyoucef \& Armani 2011). Kumar et al. (2010) explained this to the better dissolution of phosphate ions and higher rate of intra-particle diffusion at higher temperature. On the other hand, Kose and Kivanc (2011) and Xu et al. (2009) reported that phosphate adsorption capacity decreased with increasing temperature. They justified that higher temperature of the solution accelerated the leakage of phosphate ions from adsorbent surface to the solution.

\section{Effect of initial phosphate concentration}

In general, the adsorption capacity of phosphate ions increased while their percentage removal decreased with increase in initial concentration of phosphate species. Mezenner and Bensmaili (2009) and Zhang et al. (2012) reported that the percentage removal of phosphate by AWs-based sorbents decreased with increasing initial concentration of phosphate. According to the authors, for a given sorbent dose, the total number of available active sites is fixed and active sites are lacking as compared to large number of active sites required for a high initial concentration of phosphate. For a specific dose of AWsbased sorbent, the amount of binding sites is unchanged. Hence, an increase in initial concentration of phosphate led to a decrease in its percentage removal. On the other hand some researchers observed that the phosphate adsorption capacity of AWs-based adsorbents increased with increasing the initial phosphate concentration (Riahi et al. 2009, Anirudhan et al. 2006, Xu et al. 2009, Kumar et al. 2010). Kumar et al. (2010) explained that the high concentration gradient or high driving force for the transfer of phosphate ions from solution to the surface of adsorbents.

\section{Effect of adsorbent dosage}

In general, phosphate removal efficiency was found to increase with an increasein the AWs-based adsorbents dose up to a certain level, and then remained constant or decreased slightly with further increase in the adsorbent dose (Ngo et al. 2016). The higher phosphate removal efficiency at higher adsorbent dose was explained by more binding sites for phosphate adsorption and larger surface area available at higher dose of adsorbent (Xu et al. 2011, Kose \& Kivanc 2011, Zhang et al. (2012). When adsorbent dose exceeded an optimum level, the phosphate removal efficiency decrease or remains constant. This could be due to the resistance to mass transfer, particle aggregates and repulsive forces between binding sites at higher dose (Ismail 2012, Mezenner \& Bensmaili 2009, Riahi et al. 2009).

\section{Effect of interfering ions}

The effect of co-existing ions on the adsorption of phosphate onto adsorbents was investigated by many researchers in an attempt to increase practical application of these adsorbents. Biswas et al. (2008) reported that foreign anions such as $\mathrm{Cl}^{-}, \mathrm{CO}_{3}{ }^{2-}$ and $\mathrm{SO}_{4}{ }^{2-}$ cause minimal interference with the adsorption of phosphate on the $\mathrm{Zr}(\mathrm{IV})$-loaded SOW gel. They justified this observation that the affinity between gel and phosphate 
was stronger than between gel and tested competing anions. Similarly, Jyothi et al. (2012) reported that foreign anions like $\mathrm{Cl}^{-}, \mathrm{SO}_{4}{ }^{2-}, \mathrm{NO}_{3}{ }^{-}, \mathrm{F}$ and $\mathrm{CO}_{3}{ }^{2-}$ with the same concentration as $\mathrm{PO}_{4}{ }^{3-}$ hardly affect the adsorption of phosphate by adsorbents. Namasivayam and Sangeetha (2004) reported that $\mathrm{Cl}^{-}, \mathrm{NO}_{3}^{-}, \mathrm{MoO}_{3}{ }^{2-}, \mathrm{VO}_{3}{ }^{-}$ insignificantly affected the phosphate removal but the presence of $\mathrm{ClO}_{4}^{-}, \mathrm{SeO}_{3}{ }^{2-}$ and $\mathrm{SO}_{4}{ }^{2-}$ with same concentration as $\mathrm{PO}_{4}{ }^{3-}$ decreased the removal of phosphate ions.

\section{Effect of contact time}

The contact time is an indicator of the rate of adsorption process. Thus, it is an important factor in evaluating the kinetics of AWs based adsorbents (Ngo et al. 2016, Eljamal et al. 2013). In many cases, the adsorption was found to be rapid and equilibrium time for the adsorption of phosphate by AWs was under one hour (Karachalios et al. 2012, Benyoucef \& Amrani 2011, Zhang et al. 2011, Yue et al. 2010). In contrast, the longer equilibrium contact time was noted by others. It was found to be 15 hours for $\mathrm{La}(\mathrm{III}), \mathrm{Ce}(\mathrm{III})$ and $\mathrm{Zr}(\mathrm{III})$ loaded SOW gels (Biswas et al. 2007, 2008), 6 hours for $\mathrm{Zr}$ (IV) loaded apple peels (Mallampati \& Valiyaveettil 2013).

\section{DESORPTION AND REGENERATION OF AWs- BASED ADSORBENTS}

Regeneration of the spent adsorbents is necessary to restore its original adsorption capacity. A suitable AWsbased adsorbent for phosphate removal should not only have high phosphate adsorption capacity and low cost but should also be readily desorption of sorbed phosphate (Loganathan 2014). Desorption of phosphate from phosphate-laden adsorbents is done by leaching of sorbed phosphate using distilled water, salts, acids and bases (Table 2).

Table 4. Comparison of phosphate desorption efficiency of different elution solution (Nguyen et al. 2014)

\begin{tabular}{|c|c|c|c|c|}
\hline Adsorbent & Elution solution & $\begin{array}{c}\text { Desorption efficiency } \\
(\%)\end{array}$ & Remark & References \\
\hline $\begin{array}{l}\text { Fe(III)-loaded } \\
\text { carboxylated polyacryl } \\
\text { amide grafted saw dust }\end{array}$ & $\begin{array}{l}\mathrm{NaOH} \\
\mathrm{Na}_{2} \mathrm{SO}_{4} \\
\mathrm{NH}_{4} \mathrm{NO}_{3}-\mathrm{HNO}_{3} \\
\mathrm{HCl} \\
\mathrm{NaCl}\end{array}$ & $\begin{array}{l}86.8 \\
73.6 \\
50.8 \\
36.8 \\
34.5\end{array}$ & $\begin{array}{l}\text { weight loss of } \\
\text { adsorbent with } \mathrm{NaOH}\end{array}$ & Unnithan et al. (2002) \\
\hline $\begin{array}{l}\mathrm{ZnCl}_{2} \text { treated coir pith } \\
\text { carbon }\end{array}$ & $\begin{array}{l}\text { Distilled water at } \\
\mathrm{pH}(2-11)\end{array}$ & $\begin{array}{c}\text { pH } 2 \sim 30, \\
\text { pH } 11: 50, \\
\text { pH 3-11:<10 }\end{array}$ & $\begin{array}{l}\text { Low desorption } \\
\text { capacity }\end{array}$ & $\begin{array}{l}\text { Namasivayam and } \\
\text { Sangeetha (2004) }\end{array}$ \\
\hline La(III)-loaded SOW & $0.4 \mathrm{M} \mathrm{HCl}$ & 85 & La was leaked & Biswas et al (2007) \\
\hline Zr(IV)-loaded SOW & $\begin{array}{l}0.4 \mathrm{M} \mathrm{HCl} \\
0.2 \mathrm{M} \mathrm{NaOH}\end{array}$ & $\begin{array}{l}\mathrm{HCl}<40 \\
\mathrm{NaOH} 95\end{array}$ & $\mathrm{Zr}$ was not leaked & Biswas et al. (2008) \\
\hline Zr(IV)-loaded SOW & $0.2 \mathrm{M} \mathrm{NaOH}$ & 93 & Zr was not leaked & Ohura et al. (2011) \\
\hline $\begin{array}{l}\mathrm{Zr}(\mathrm{IV}) \text {-loaded apple } \\
\text { peel }\end{array}$ & $\begin{array}{l}\text { Distilled water at } \\
\mathrm{pH} 12\end{array}$ & 90 & $\mathrm{Zr}$ was not leaked & $\begin{array}{l}\text { Mallampati and } \\
\text { Valiyaveettil (2013) }\end{array}$ \\
\hline Fe(III)-loaded okara & $\begin{array}{l}\text { Distilled water at } \\
\mathrm{pH} 12,0.25 \mathrm{NaOH}, \\
0.1 \mathrm{M} \mathrm{HCl}\end{array}$ & $>94$ & $\mathrm{Fe}(\mathrm{III})$ was leaked & Nguyen et al. (2013) \\
\hline Zr(IV)-loaded okara & $0.2 \mathrm{M} \mathrm{NaOH}$ & 97.8 & Zr was not leaked & Nguyen et al. (2014c) \\
\hline
\end{tabular}

Some researchers have used distilled water as eluting agent to reduce the cost of chemicals used for desorption and remove adverse impacts on the environment (Namasivayam \& Sangeetha 2004, Mallampati \& Valiyaveettil 2013). Neutral salts (e.g. $\mathrm{NaCl}, \mathrm{KCl}$ ) are another means of desorption of phosphate from ladenadsorbents. Loganathan et al. (2014) suggested that neutral salts were effective eluting agents for weak and reversible adsorption, where ion exchange could be an important pathway for the adsorption of phosphate. But for strong and less reversible sorption, which is controlled by ligand exchange, surface precipitation or chemisorptions, the efficiency of these salts was usually low. The higher concentration of neutral salts seem to support desorption.

In some cases, to increase the desorption capacity of phosphate, distilled water and neutral salts have been replaced by acids or bases. Among these, $\mathrm{NaOH}$ and $\mathrm{HCl}$ were widely used. Generally, $\mathrm{NaOH}$ and $\mathrm{HCl}$ exhibited 
high desorption capacities (Ngo et al. 2016). For example desorption efficiency was found to be $85 \%$ for $0.4 \mathrm{M} \mathrm{HCl}$ (Biswas et al. 2007), $95 \%$ for $0.2 \mathrm{M} \mathrm{NaOH}$ (Biswas et al. 2008), $97.8 \%$ for $0.2 \mathrm{M} \mathrm{NaOH}$ (Nguyen et al. 2014c). High efficiency of acids or bases could be explained by low affinity of dominant phosphate species like $\mathrm{H}_{3} \mathrm{PO}_{4}$ (in acidic medium), $\mathrm{HPO}_{4}{ }^{2-}$ and $\mathrm{PO}_{4}{ }^{3-}$ (in alkaline medium), toward binding site on AWs surface. Another probable reason for that was the replacement of phosphate anion bound to the MLAWs by $\mathrm{OH}^{-}$ions in alkaline medium. The reported results indicated that, acid and bases are superior to neutral salts in desorbing phosphate in case of strong adsorption. However, their application could result in some side effects like loss in the adsorption capacity as well as loss of weight of adsorbents. This is due to the leakage of loaded metal ions from the MLAWs-based adsorbent (Biswas et al. 2007). The weight loss of adsorbents may be due to corrosion of cellulose/hemicellulose structure (Ngo et al. 2016).

\section{CONCLUSIONS}

Although various techniques are currently available, adsorption has been proven to be an effective, reliable and environmentally benign process for the removal of phosphate from wastewater. Due to the lack of anion binding sites, raw AWs are inefficient in phosphate removal. Consequently, raw AWs can be modified for developing better phosphate adsorbents. In this review, most widely used metal-loading methods have been explored. MLAWs exhibit an equal to or even a higher phosphate adsorption capacity than some well-known commercial adsorbents. The ligand exchange and surface precipitation are reported mechanism for the adsorption of phosphate onto MLAWs-based adsorbents. Of influential factors, $\mathrm{pH}$ appears to play the critical role.

In most of the cases, MLAWs exhibited high phosphate adsorption capacity in a short time $(<1 \mathrm{~h})$, in the presence of co-existing ions $\mathrm{Cl}^{-}, \mathrm{NO}_{3}^{-}, \mathrm{SO}_{4}{ }^{2-}, \mathrm{CO}_{3}{ }^{2-}$ etc., over a wide $\mathrm{pH}$ range of 4-9. The aforementioned properties provide suitable conditions for their practical applications. Phosphate laden adsorbents can be regenerated easily up to $80 \%$ or more of the adsorption capacity by simply using distilled water, salts, acids and bases. Though many original research articles are available on MLAWs-based adsorbents, most of them are limited to batch-scale and there is no further scale up of the process for the treatment of real industrial effluents. Hence, further research is necessary in this field.

As a final remark, MLAWs-based adsorbents offer significant advantages over commercially available expensive adsorbents for removal/recovery of phosphate from wastewater. It is also reasonable to understand that improvement in the current modification techniques to develop AWs-based adsorbents for removal of phosphate from wastewater is still an emerging field of research which requires further exploration of innovative methods to develop more efficient AWs-based adsorbents.

\section{REFERENCES}

Anirudhan, T.S. and Senan, P. 2011. Adsorption of phosphate ions from water using a novel cellulose based adsorbent. Journal of Chemical Ecology 27(2): 147-164.

Anirudhan, T.S., Noelin, B.F. and Manohar, D.M. 2006. Phosphate removal from wastewater using a weak anion exchange prepared from a lignocelluslosic residue. Environmental Science \& Technology 40: 2740-2745.

Anirudhan, T.S., Rauf, T.A. and Rejeena, S.R. 2012. Removal and recovery of phosphate ions from aqueous solutions by amine functionalized epichlorohydrin- grafted cellulose. Desalination 285: 277-284.

Aryal, M. and Liakopoulou-Kytriakides, M. 2011. Equilibrium, kinetics and thermodynamic studies on phosphate biosorption from aqueous solution by $\mathrm{Fe}(\mathrm{III})$ treated Staphylococus xylosus biomass: common ion effect. Colloids and Surfaces A: Physicohemistry Engineering Aspects 387: 43-49.

Auwal, M.R., Jyo, A., Ihara, T., Seko, N., Tamada, M. and Lin. K.T. 2011. Enhanced trace phosphate removal from water by zirconium(IV) loaded fibrous adsorbent. Water Resource 45: 4592-4600.

Benyoucef, S. and Amrani, M. 2011. Adsorption of phosphate ions onto low cost aleppo pine adsorbent. Desalination 275: 231-236.

Bhattarai, P., Bohra, K.P. and Pokhrel, M.R. 2015. Adsorptive removal of As(III) from aqueous solution. Journal of Institute of Science and Technology 19(1): 150-154.

Bhojappa, S. 2009. Removal of phosphorous/selenium from aqueous solution by adsorption process. Master Thesis, West Virginia University, Morgantown, West Virginia, USA.

Biswas, B.K. 2008. Removal and recovery of arsenic and phosphorous by means of adsorption onto orange waste, an available agricultural by-product. Doctoral Dissertation, Department of Applied Chemistry, Saga University, Japan.

Biswas, B.K., Inou, K., Ghimire, K.N., Ohta, S., Harada, H., Ohto, K. and Kawakita, H. 2007. The adsorption of phosphate from and aquatic environment using metal loaded orange waste. Journal of Colloid and Interface Science 312: 214-223.

Biswas, B.K., Inoue, K., Ghimire, K.N., Harada, H., Ohto, K., and Kawakita, H. 2008. Removal and recovery 
of phosphorous from water by means of adsorption onto orange waste gel loaded with zirconium. Bioresource Technology 99(18): 8685-8690.

Bouamra, F., Drouiche, N., Abdi, N., Grib, H., Mameri, N. and Lounici, H. 2018. Removal of phosphate from waste water by adsorption on marble waste: effect of process parameters and kinetic modeling. International Journal of Environmental Research 12(1): 13-27.

Carvalho, W.S., Martins, D.F., Gomes, F.R., Leite, I.R., Silva, L.G., Ruggiero, R., and Richter, E.M. 2011. Phosphate adsorption on chemically modified sugarcane bagasse fibres. Biomass and Bioenergy 35: 3913-3919.

De-Bashan, L.E. and Bashan, Y. 2004. Recent advances in removing phosphorous from wastewater and its future use as fertilizer (1997 - 2003). Water Research 38: 4222-4246.

Du, W., Li, Y., Xu, X., Shang, Y., Gao, B. and Yue, Q. 2019. Selective removal of phosphate by dual $\mathrm{Zr}$ and La hydroxide/ cellulose-based bio-composites. Journal of Colloid and Interface Science 533: 692699.

Eberhardt, T.L. and Min, S.H. 2008. Biosorbents prepared from wood particles treated with anionic polymer and iron salt: effect of particle size on phosphate adsorption. Bioresource Technology 99: 626-630.

Eljamal, O., Okawauchi, J., Hiramatsu, K. and Harada M. 2013. Phosphorous sorption from aqueous solution using natural materials. Environmental Earth Sciences 68: 859-863.

Geng, Y.K., Wang, Y., Pan, X.R. and Sheng, G.P. 2018. Electricity generation and in situ phosphate recovery from enhanced biological phosphorus removal sludge by electro dialysis membrane bioreactor. Bioresource Technology 247: 471-476.

Goh, K.H., Lim, T.T. and Dong, Z. 2008. Application of layered double hydroxides for removal of oxy anions: A review. Water Research 42: 1343-1368. .

Gupta, V.K., Carrott, P.J.M., Ribeiro Carrott, M.M.L. and Suhas. 2009. Low-cost adsorbent: growing approach to wastewater treatment-a review. Critical Review in Environmental Science \& Technology 39(10): 783-842.

Han, J.S., Min, S. and Kim, Y. 2005. Removal of phosphorous using AMD-treated lignocellulosic material. Forest Products Journal 55(11): 48-53.

HMG/MoPE. 2012. Tolerance limit for industrial (wastewater) effluents discharged into inland surface water. Nepal Gazette, generic standards, Nepal Government.

Hokkanen, S., Bhatnagar, A. and Sillanpää, M. 2016. A review on modification methods to cellulose based adsorbents to improve adsorption capacity. Water Research 91: 156-173.

Huang, W., Zhang, Y. and Li, D. 2017. Adsorptive removal of phosphate from water using mesoporus materials: a review. Journal of Environment management 193: 470-482.

Huang, X., Liao, X. and Shi, B. 2009. Adsorption removal of phosphate in industrial wastewater by using metal loaded skin split waste. Journal of Hazardous Materials 166: 1261-1265.

Inoue, K., Harada, H., Ghimire, K.N., Biswas, B.K., Kawakita, H. and Ohto, K. 2018. Adsorptive removal of phosphorous using metal-loaded biosorbents from aquatic environment. JOJ Materials Science 4(2): 555632.

Irdemez, S., Demircioglu, N., Yildiz, Y.S. and Bingul, Z. (2006). The effects of current density and phosphate removal from water by electro coagulation using aluminum and iron plate electrodes. Separation and Purification Technology 52(2): 218-233.

Ismail, Z.Z. 2012. Kinetic study for phosphate removal from water by recycled date-palm wastes as agricultural by-products. International Journal of Environmental studies 69(1): 135-149.

Jung, K.W., Jeong, T.U., Choi, J.W., Ahn, K.H. and Lee, S.H. 2017. Adsorption of phosphate from aqueous solution using electrochemically modified biochar calcium-alginate beads: batch and fixed bed column. Bioresource Technology 244: 23-32.

Jutidamrongphan, W., Park, K.Y., Dockko, S., Choi, J.W. and Lee, S.H. 2012. High removal of phosphate from waste water using silica sulphate. Environmental Chemistry Letters 10: 21-28.

Jyothi, M.D., Kiran K.R. and Ravindhranath, K. 2012. Phosphate pollution control in waste waters using new biosorbents. International Journal of Water Resources and Environmental Engineering 4(4): $73-$ 85.

Kalmykova, Y. and Fedje, K. 2013. Phosphorous recovery from municipal solid waste incineration fly ash. Waste Management 33: 1403-1410.

Karachalios, A.P. 2012. Nutrient removal from water by various quaternized wood agriculture residues using a choline based ionic liquid analogue. Doctoral Dissertation, Stevens Institute of Technology, Hoboken, New Jersey. 
Kose, T.E., and Kivanc, B. 2011. Adsorption of phosphate from aqueous solution using calcined waste eggshell. Chemical Engineering Journal 178: 34-39.

Kour, J. 2016. Regeneration and reuse of biomaterial for the removal of cadmium ions from waste water. Journal of Institute of Science and Technology 21(1): 90-94.

Krishnan, K.A., and Hardias, A. 2008. Removal of phosphate from aqueous solutions and sewage using natural and surface modified coir pith. Journal of Hazardous Materials 152: 527-535.

Kumar, P., Sudha, S., Chand, S. and Srivastava, V.C. 2010. Phosphate removal from aqueous solution using coir pith activated Carbon. Separation Science and Technology 45: 1463-1470.

Liao, T., Li, T., Su, X., Yu, X., Song, H., Zhu, Y. and Zhang, Y. 2018. $\mathrm{La}(\mathrm{OH})_{3}$-modified magnetic pineapple biochars as novel adsorbents for efficient phosphate removal. Bioresource Technology 263: 207-213.

Lin, J., Zhan, Y., Wang, H., Chu, M., Wang, C., He, Y. and Wang X. 2016. Effect of calcium ion on phosphate adsorption onto hydrous zirconium oxide. Chemical Engineering Journal 309: 118-129.

Liu, R., Chi, L, Wang, X., Sui, Y., Wang, Y. and Arandiyan, H. 2018. Review of metal (hydr) oxide and other adsorptive materials for phosphate removal from water. Journal of Environmental Chemical Engineering 6(4): 5269-5286.

Liu, R., Chi, L., Wang, X., Wang, Y., Sui, Y., Xie, T. and Arandiyan, H. 2019a. Effective and selective adsorption of phosphate from aqueous solution via trivalent-metals-based amino-MIL-101 MOFs. Chemical Engineering Journal 357: 159-168.

Liu, T., Wu, K. and Zeng, L. 2012. Removal of phosphorous by a composite metal oxide adsorbent derived from manganese ore tailings. Journal of Hazardous Materials 217-218: 29-35.

Liu, Y., Gao, Q., Pu, S., Wang, H., Xia, K., Han, B. and Zhou, C. 2019b. Carboxyl-functionalized lotus seedpod: A highly efficient and reusable agricultural waste-based adsorbent for removal of toxic $\mathrm{Pb}^{2+}$ ions from aqueous solution. Colloids and Surfaces A: Physicochemical and Engineering Aspects 568: 391401.

Loganathan, P., Vigneswaran, S., Kandasamy, J. and Bolan, N.S. 2014. Removal and recovery of phosphate from water using sorption. Critical Reviews in Environmental Science \& Technology 44(8): 847-907.
Mallampati, R. and Valiyaveettil, S. 2013. Apple peel- a versatile biomass for water purification. ACS Applied Materials and Interfaces 5: 4443-4449.

Markou, G., Mitrogiannis, D., Muylaert, K., Çelekli, A. and Bozkurt, H. 2016. Biosorption and retention of orthophosphate onto $\mathrm{Ca}(\mathrm{OH})_{2}$-pretreated biomass of Phragmites sp. Journal of Environmental Sciences, 45: 49-59.

Marshall, W.E. and Wartelle, L.H. 2004. An anion exchange resin from soybean hulls. Journal of Chemical Technology and Biotechnology 79: 12861292.

Mezenner, N.Y. and Bensmaili, A. 2009. Kinetics and thermodynamic study of phosphate adsorption on iron hydroxide eggshell waste. Chemical Engineering Journal 147: 87-96.

Mor, S., Chhoden, K. and Ravindra, K. 2016. Application of agro-waste rice husk ash for the removal of phosphate from the wastewater. Journal of Cleaner Production 129: 673-680.

Mor, S., Chhoden, K., Negi, P. and Ravindra, K. 2017. Utilization of nano-alumina and activated charcoal for phosphate removal from wastewater. Environmental Nanotechnology Monitoring \& Management 7: 15-23.

Morse, G.K., Brett, S.W., Guy J.A. and Lester, J.N. 1998. Review: phosphorous removal and recovery technologies. Science of the Total Environment 212: 69-81.

Nada, A.M.A. and Hassan, M.L. 2006. Ion exchange properties of carboxylated bagasse. Journal of Applied Polymer Science 102: 1399-1404.

Namasivayam, C., Sakoda, A. and Suzuki, M. 2005. Removal of phosphate by adsorption onto oyster shell powder-kinetic studies. Journal of Chemical Technology and Biotechnology 80: 356-358.

Namasivayanm, C., and Sangeetha, D. 2004. Equilibrium and kinetic studies of adsorption of phosphate onto $\mathrm{ZnCl}_{2}$ activated coir pith carbon. Journal of Colloid and Interface Science 280: 359-365.

Naushad, M., Sharma, G., Kumar, A., Sharma, S., Ghfar, A.A., Bhatnagar, A., Stadler, F.T. and Khan, M.R. 2018. Efficient removal of toxic phosphate anions from aqueous environment using pectin based quaternary amino anion exchanger. International Journal of Biological Macromolecules 106: 1-10.

Ngo, H.H., Guo, W., Nguyen, T.A.H., Surampalli, R.Y. and Zhang, T.C. 2016. Agricultural by-products for phosphorous removal and recovery from water and 
wastewater: a green technology. Green Technology for Sustainable Water Management.

Nguyen, T.A.H., Ngo, H.H., Guo, W.S., Zhou, J.L., Wang, J., Liang, H. and Li, G. 2014b. Phosphorus elimination from aqueous solution using zirconium loaded okara as a biosorbent. Bioresource Technology 170: 30-37.

Nguyen, T.A.H., Ngo, H.H., Guo, W.S. and Nguyen, T.V. 2012. Phosphorous removal from aqueous solutions by agricultural by-products: a critical review. Journal of Water Sustainability 2(3): 193-207.

Nguyen, T.A.H., Ngo, H.H., Guo, W.S., Zhang, J., Liang, S., Lee, D.J., Nguyen, P.D. and Bui, X.T. 2014a. Modification of agricultural waste/by-products for enhanced phosphate removal and recovery: potential and obstacles. Bioresource Technology 169: 750672 .

Nguyen, T.A.H., Ngo, H.H., Guo, W.S., Zhang, T; Liang, S. and Tung, K.L. 2013. Feasibility of iron loaded 'okara' for biosorption of phosphorous in aqueous solutions. Bioresource Technology 150: 42-49.

Nguyen, T.A.H; Ngo, H.H., Guo, W.S., Nguyen, T.V., Zhang, T., Liang, S., Chen, S.S. and Nguyen, N.C. 2014c. A comparative study on different metal loaded soybean milk by product okara for biosorption of phosphorous from aqueous solution. Bioresource Technology 169: 291-298.

Ohura, S., Harada, H., Biswas, B.K., Kondo, M., Ishikawa, S., Kawakita, H., Hoto, K. and Inoue, K. 2011. Phosphorous recovery from secondary effluent and side stream liquid in a sewage treatment plant using zirconium loaded saponified orange waste. Journal of Materials Cycles and Waste Management 13: 293-297.

Paudyal, H. and Inoue, K. 2018. Adsorptive removal of trace concentration of fluoride from water using cerium loaded dried orange juice residue. Journal of Institute of Science and Technology 23: 43-48.

Paudyal, H., Pangeni, B., Inoue, K., Matsueda, M., Suzuki, R., Kawakita, H., Ohto, K., Biswas, B.K., and Alam, S. 2012. Adsorptive behavior of fluoride ions on Zirconium(IV)-loaded orange waste gel from aqueous solution. Separation Science and Technology 41: 96-103.

Peleka, E.N. and Deliyanni, E.A. 2009. Adsorptive removal of phosphate from aqueous solutions. Desalination 245: 357-371.

Peng, F., He, P., Luo, Y., Lu, X., Liang, Y. and Fu, J. 2012. Adsorption of phosphate by biomass chars deriving from fast pyrolysis of biomass waste. Clean-soil, Air, Water 40(5): 493-498.
Pradhan, S. and Pokhrel, M.R. 2013. Spectrophotometric determination of phosphate in sugarcane juice, fertilizer, detergent and water samples by molybdenum blue method. Scientific World 11(11): 58-62.

Regmi, S., Ghimire, K.N., Pokhrel, M.R. and Khadka, D.B. 2015. Adsorptive removal and recovery of aluminium (III), iron (II), and chromium (VI) onto a low cost functionalized phragmities karka waste. Journal of Institute of Science and Technology 20(2): 145-152.

Riahi, K., Thayer, B.B., Mammou, A.B., Ammar, A.B. and Jaafoura, M.H. 2009. Biosorption characteristics of phosphates from aqueous solution onto Phoenix dactylifera L. date palm fibers. Journal of Hazardous Materials 170: 511-519.

Shin, E.W., Karthikeyan, K.G. and Tshabalala, M.A. 2005. Ortho phosphate sorption onto lanthanum treated lignocellulosic sorbents. Environmental Science \& Technology 39: 6273-6279.

Shrestha, S., Poudel, B.R., Silwal, M. and Pokhrel, M.R. 2018. Adsorptive removal of phosphate onto ironloaded Litchi chinesis seed waste. Journal of Institute of Science and Technology 23: 81-87.

Shyla, B. and Nagendrappa, G. 2011. A simple spectrophotometric method for the determination of phosphate in Soil, detergents, water, bone and food samples through the formation of phosphomolybdate complex followed by its reduction with thiourea. Spectrochimica Acta Part A: Molecular and Biomolecular Spectroscopy 78: 497-502.

Slomp, C.P. and Chappellen, P.V. 2007. The global marine phosphorous cycle: sensitivity to oceanic circulation. Biogeoscience 4: 155-171.

Tanaka, T. and Simamura, K. 2005. Biological wastewater treatment process with chemicalphosphorous recover reactor. Journal of Environmental Biotechnology 4(2):101-108.

Thapa, S. and Pokhrel, M.R. 2013. Removal of As(III) from aqueous solution using $\mathrm{Fe}(\mathrm{III})$ loaded pomegranate waste. Journal of Nepal Chemical Society 30: 29-36.

Tian, Y.S., He, W.H., Zhu, X.P., Yang, W.L., Ren, N.Q. and Logan, B.E.K. 2017. Improved electro coagulation reactor for Rapid removal of phosphate from wastewater. ACS Sustainable Chemistry and Engineering 5(1): 67-71.

Unnithan, M.R., Vinod, V.P. and Anirudhan, T.S. 2002. Ability of iron(III)-loaded carboxylated polyacrylamide-grafted sawdust to remove phosphate ions from aqueous solution and fertilizer 
industry wastewater. Adsorption kinetics and isotherm studies. Journal of Applied Polymer Science 84(13): 2541-2553.

Wang, S., Ang, H.M. and Tade, M.O. 2008. Novel applicaions of red mud as coagulant, adsorbent and catalyst for environmentally benign processes. Chemosphere 72: 1621-1635.

Wang, X., Liu, Z., Liu, T., Huo, M., Huo, H. and Yang, W. 2015. Removing phosphorous from aqueous solutions using lanthanum modified pine needles. PLoS ONE 10(12): e0142700. doi:10.1371/journal.pone.0142700.

Wang, Z., Nie, E., Li, J., Yang, M., Zhao, Y., Luo, X. and Zheng, Z. 2012. Equilibrium and kinetics of adsorption of phosphate onto iron-doped activated carbon. Environmental Science and Pollution Research 19: 2908-2917.

WHO 1993. Guidelines for drinking water quality. WHO guidelines, World Health Organization.

Xu, X., Gao, B., Wang, W., Yue, Q., Wang, Y. and Ni, S. 2009. Adsorption of phosphate from aqueous solutions onto modified wheat residue: characteristics, kinetic and column studies. Colloids \& Surfaces B: Biointerfaces 70: 46-52.

Xu, X., Gao, B., Yue, Q. and Zhong, Q. 2011. Sorption of phosphate on to gaint reed based adsorbent: FTIR, raman spectrum analysis and dynamic sorption/desorption properties in filter bed. Bioresource Technology 102: 5278-5282.

Xu, X., Gao, B.Y., Yue, Q.Y, Zhong, Q.Q. and Zhan, X. 2010. Preparation, characterization of what residue based anion exchanger and its utilization for the phosphate removal from aqueous solution. Carbohydrate Polymers 82: 1212-1218.

Yadav, D., Kumar, P., Kapur, M. and Mondal, M.K. 2018. Phosphate removal from aqueous solutions by nanoalumina for the effective remediation of eutrophication. Environmental Progress \& Sustainable Energy 38: S77-S85.

Yeom, S.H., and Jung, K. 2009. Recycling wasted scallop shell as an adsorbent for the removal of phosphate. Journal of Industrial \& Engineering Chemistry 15(1): 40-44

Zhang, J., Shan, W., Ge, J., Shen, Z., Lei, Y. and Wang, W. 2012. Kinetic and equilibrium studies of liquid phase adsorption of phosphate on modified sugarcane bagasse. Journal of Environmental Engineering 138: 252-258.

Zhang, L., Wan, L., Chang, N. Liu, J., Duan, C., Zhou, Q. and $\mathrm{Li}, \mathrm{X} .22011$. Removal of phosphate from water by activated carbon fiber loaded with lanthanum oxide. Journal of Hazardous Materials 190: 848855. 